\title{
Tropes of Racialization in the Works of Natsume Sōseki
}

This chapter complements the previous one, analyzing the works of Natsume Sosseki by returning to the tropes of racialization. As I stated in the introduction, I seek to make several interventions by bringing in Sōseki here. First, this will allow me to address one problem in Japan Studies scholarship where Ueda is often attacked as an evil linguistic nationalist while Sōseki is deemed a figure of resistance to nationalism and imperialism. Such a tendency is extremely reductive, as it refuses to consider modernity in a structural sense.

Second, apart from a few essays on rhetoric that Sōseki wrote-like "Shaseibun" ("On Sketching," 1907) and "Sōsakuka no taido" ("On the Attitude of Creators," 1908)-Sōseki's works are rarely taken up in the scholarship on language reform. Of course, Sōseki was a fiction writer, but his theoretical works, such as Bungakuron (Theory of Literature, 1906) and Bungaku hyöron (Literary Criticism, 1907), offer a radical view of language, providing a unique alternative to those of Ueda and the other advocates of reform. Furthermore, they responded to a shared historical time. As we shall see below, not only Ueda but Sōseki also engaged with the notion of literary history prevalent in their era.

Finally, introducing race into this dynamic is an important intervention in itself. Race studies have long contemplated the link between race and language, while studies of language reform have continued to efface the inextricable role race played in the formation of "national languages." The concealment of such major indexes of identity-which the proponents themselves often recognized-should by no means be reified through our practices. As I will delineate later in the chapter, Japan Studies in North America has been complicit in the effacing of race as a major index of identity.

In order to free race from biologism, I will continue to construe race not as a fixed category, but as a fluid one. As I have discussed, "civilization," and hence 
race, embodies a movement toward "whiteness." The telos that is "whiteness" is inextricably linked to "privilege," whether it be the "West" in all its incarnations, social status, "cultivated taste," or the "proper" use of language-such as pronunciation, grammar, and so forth. These are means to racialize and thus produce a hierarchy among people. Without thinking about race in this way, it is impossible to understand how racial categories have transformed throughout the course of history. Such a view of race is vital to analyzing Sōseki's works and, more broadly, to understanding the complexity of race that lies at the core of modernity.

Although the primary focus of this chapter is Sōseki's theoretical works, I will first discuss his other works, particularly Sanshirō (1908) and "Mankan tokoro dokoro" ("Travels in Manchuria and Korea," 1909) where tropes of racialization surface compellingly. I do so for two primary reasons. The first is to show how conscious Sōseki was about race, how racial tropes figure ubiquitously in his works. Second, it will also allow me to highlight the problematics of Sōseki scholarship, especially the way scholars treat racial tropes evident in his works. I should add here that my interest is not to determine whether Sōseki was a nationalist or not or even racist or not. Such questioning is itself rather naïve, as it individualizes issues that are by nature structural. By uncovering the tropes of racialization embedded in his works, I will show that the complexity of race and nation eludes such manner of problematization.

\section{THE FLUIDITY OF RACE IN SŌSEKI'S WORKS}

As I mentioned, there has been a strong trend in Sōseki scholarship to valorize him as an anti-imperialistic, anti-colonialist figure. Komori Yōichi has, in his various works on Sōseki, been representative of this trend, but he is definitely not alone. ${ }^{1}$ In the last decade or so, however, this trend has begun to be questioned. Park Yuha, for example, boldly shows in her Nashonaru aidentitī to jendā (National Identity and Gender) that such an image is symptomatic of a desire to make Sōseki more admirable than he actually was, and is the mere result of disavowing the many textual manifestations of Sōseki's clear imperialistic tendencies. In addition, Shibata Shōji's Sōseki no naka no "teikoku” ("Empire” Within Sōseki) also examines the ubiquity of imperialist discourse in Sōseki's oeuvre. As these works show, Sōseki was very much a product of his time.

Valorization of the West, together with anti-Chinese sentiment, defined Japan's modernization process in a variety of ways, and these appear everywhere in Sōseki's fiction, essays, journal, and letters. One obvious example is "Mankan tokoro dokoro," a travelogue that he wrote based on his visit to the colonies upon the invitation by the then president of the South Manchurian Railway Company, Nakamura Zekō (1867-1927). The following is a notorious passage where Sōseki describes the "Chinese coolies" that he sees upon arriving in Manchuria: 
On the pier, there were crowds of people; most of the people there, however, were Chinese coolies. Even one of them appeared filthy, but two together was even more unsightly (migurushii). When they were all huddled together, however, it was indecent (futeisai). . . . As soon as we had docked, the crowd of coolies started buzzing and swarming like angry wasps. ${ }^{2}$

As many scholars have pointed out, Sōseki here uses the discourse of hygiene, a discourse of modern superiority. Sōseki further animalizes the "coolies" here. In fact, throughout the text, he repeatedly characterizes the "coolies" as having physical prowess that Japanese could never have, endowing the former with a rather primitive animalism. Such an association between coolies and animals is clearly on par with a common racist discourse to which the Japanese were also subjected, as the Russian Tsar Nicholas II famously referred to the Japanese as "monkeys" during the Russo-Japanese War.

Scholars have debated much about this kind of vulgar racism in "Mankan tokoro dokoro," but there are also more subtle forms of racial tropes in this text. Take a look at the following passage, where Sōseki expresses a sense of surprise upon finding beautiful architecture in Fushun when visiting a coal mine:

When we went up on to the embankment where the water tower had been erected, I was able to take in the whole town at a glance. It had not yet been completed, but all the buildings were brick and the architecture was even worthy of illustration in Studio. One would have never imagined that this place was managed by Japanese. ... The buildings included a church, theater, hospital, school, and, needless to say, the miners' living quarters. It would have been great to take them to the center of Tokyo and gaze at during a walk. When we asked Matsuda, he informed us that they had been built exclusively by Japanese engineers (SZ 16:253; tr. 133).

The buildings do not appear to be "managed by Japanese," suggesting that they look "Western" as they are "worthy of illustration" in the English journal Studio. Sōseki is then told that they were indeed built by Japanese engineers. The center shifts here-the West is the ultimate center, but the Japanese, who are capable of reproducing such buildings in Fushun, act "white" in the colonies. The desire to make Japan "white" exists strongly in Sōseki, as it did in many of his contemporaries.

We must be cautious about overemphasizing what we may refer to as "vulgar racism," as this might make us lose sight of the complexity that is involved in the issue of race. Take the following passage from Park, where she discusses Sōseki's overtly imperialistic gaze, inscribed in his characterization of the same "Chinese coolies":

Sōseki's gaze vis-à-vis this 'filth' is clearly in accord with that of the South Manchurian Railway Company $(\mathrm{SMR})=$ imperialism. What brings about this gaze is precisely the self-awareness of an 'enlightened figure' (bunmeijin) that, like the SMR, attempts to exclude the unhygienic and unsanitary. Such a gaze, shared by the SMR and Sōseki, goes beyond the simple sense of surprise in seeing "differences" and becomes 
"discriminatory." This was precisely because hygiene had established itself as an ideology for the strong nation-state, which invariably produced discrimination. When such a gaze is projected on to other ethnicities and nations, it produces racism. ${ }^{3}$

To be fair to Park, I must add here that she is arguing against scholars who view Sōseki as an anti-imperialistic and anti-colonialist figure who existed beyond racism. Too many scholars, including such critics as Kawamura Minato, have taken up "Mankan tokoro dokoro" and remarked that Sōseki was being "humorous," and hence "lacked the feeling of racism." 4 Yet Park's desire to establish Sōseki as an imperialist figure leads her, perhaps inadvertently, to simplify racism and categories of ethnic difference. I do not disagree that the gaze here is imperialistic. But racism is not limited to such a gaze being "projected on to other ethnicities and other nations," as Park claims. This gaze is racist even within a single nation or ethnicity. To perceive racism only when such a gaze is applied to other nationalities or ethnicities can only reify and ultimately endorse the biologism of racial or ethnic categories. In effect, despite Park's desire to expose Sōseki's uncritical application of imperialist tropes, her failure to question the fixed binary of self and other makes her own work complicit with this same structure of racism.

We must again remind ourselves that neither race nor ethnicity is a fixed category. In fact, as we shall see later, the same racializing gaze is, in Sōseki's works, projected onto others within the confines of Japan. I should also add that Park is in fact quite conscious of the internal hierarchy that exists within Japan. In her other chapters on Sōseki, for example, she explores how the countryside is discovered as an "inferior" place, against which Tokyo as center can claim its status as enlightened. Significantly, however, race is not introduced in this discussion. That is to say, Park would not characterize this as racial discrimination. Despite her otherwise compelling analysis of imperialist discourse in Sōseki, she either disregards race or only mobilizes it when it is projected onto an ethnic or national other. I cannot stress highly enough the importance of freeing the discussion of race from biologism and reified ethnic categories. If we consider racism to be produced only when national or ethnic boundaries are crossed, we inevitably fix race as that which exists objectively in the world.

Such biologism further makes us lose sight of the complex ways in which Sōseki addressed the issue of race. Take his 1908 Sanshirō, for example. At the beginning of this well-known novel, the namesake protagonist travels to Tokyo from his native Kyūshū to begin his illustrious career at Tokyo Imperial University. At the time, one had to be a graduate of one of eight kōtō gakkō (or "colleges") around the country to even be eligible to take the entrance examination at Tokyo Imperial University, thus effectively marking Sanshirō as "white" and part of the elite. Yet he is also "black," as he is described as a "black man from Kyūshū" (Kyūshu no otoko de iro ga kuroi) who is likened to the African prince Oroonoko. ${ }^{6}$ As the train travels to Tokyo, Sanshirō notices women's skin color "gradually becoming whiter" 
(shidai ni shiroku naru) (5). Precisely because of this, Sanshirō notices the woman he ends up spending the night together with at an inn in Nagoya, characterizing her as "iro ga kuroi," or "black," which he further describes as a "Kyūshū color" (5). In Meiji Japan, Tokyo was a center marked as white, while Kyūshū was a "backward" site associated with "black" people. Kyūshū continues to be described as a "backward" site, as shown by Sanshirōs dialogue with a fellow student:

'Where did you go to college?'

'Kumamoto'.

'Oh, really? My cousin went there. I heard it's a terrible place'

'Yes, barbaric' (142; tr. 114).

What is important here is that racial hierarchy is mobilized not only with the nonJapanese, but within the confines of Japan itself. In other words, contrary to what Park believes, anyone can be subjected to this racial discourse in Sōseki's works. Moreover, race is not fixed in Sanshirō, as mobility is not restrictive, which is evident from the fact that Sanshirō, a "black man" from Kyūshū, can become "white" as a Tokyo Imperial University student. Using the movement of the train from Kyūshū to Tokyo, which aligns with skin color "gradually becoming whiter," Sōseki suggests a teleological movement toward whiteness, a movement toward civilization, here clearly embodied by Sanshirō.

To further this racialization of center-periphery, Sanshirō even hierarchizes "Westerners." Take the following scene where Sanshirō and a man whom we later discover is Hirota Sensei encounter "Westerners" at a train station:

Sanshirō noticed four or five Westerners strolling back and forth past the train window. One pair was probably a married couple; they were holding hands in spite of the hot weather. Dressed entirely in white, the woman was very beautiful. Sanshirō had never seen more than half a dozen foreigners in the course of his lifetime. Two of them were his teachers in college, and unfortunately one of those was a hunchback. He knew one woman, a missionary. She had a pointed face like a smelt or a barracuda. Foreigners as colorful and attractive as these were not only something quite new for Sanshirō, they seemed to be of a higher class $(j \bar{o} t \bar{o})$. He stared at them, entranced. Arrogance from people like this was understandable. He went so far as to imagine himself traveling to the West and feeling insignificant among them. When the couple passed his window he tried hard to listen to their conversation, but he could make out none of it. Their pronunciation was nothing like that of his Kumamoto teachers (19; tr. 15).

Just as the Kyūshū Japanese are racially marked as "inferior" to those in Tokyo, so too are the Westerners here. In comparison to the beautiful couple that Sanshirō sees, the Westerners in Kyūshū whom he had met were a "hunchbacked" teacher or a woman with a face like a fish. Moreover, the pronunciation of the language 
they speak, which is clearly a marker of class, had been entirely different from that of the Westerners in Kumamoto. In other words, in Sanshirō even the Westerners become "whiter" as they approach Tokyo, which greatly highlights the fluidity of race. In more ways than one, what Sōseki demonstrates is that there is no essential whiteness, for this category is internally divided. We can only speak of whiteness in the plural, and this difference is profoundly hierarchal.

Hirota's view, on the other hand, appears to reify the common understanding of Westerners. Looking at the same couple, he says the following:

'Beautiful', he murmured, releasing a languorous little yawn. Sanshirō realized what a country boy he must appear; he drew his head in and returned to his seat. The man sat down after him. 'Westerners are very beautiful, aren't they?' he said. . . 'We Japanese are sad-looking things next to them. We can beat the Russians, we can become a "first-class power," but it doesn't make any difference. We still have the same faces, the same feeble little bodies' (20; tr. 15).

Hirota homogenizes the Westerners as a superior race, while degrading all Japanese as having the "same faces, the same feeble bodies." Later in the novel, Sanshirō asks Yojirō about Hirota: "He talks about how dirty Tokyo is and how ugly the Japanese are, but has he ever been abroad?" Yojirō responds, "Are you kidding? ... He's like that because his mind is more highly developed than anything in the actual world. One thing he does do is study the West in photographs. He's got tons of them-the Arc de Triomphe in Paris, the Houses of Parliament in London-and he measures Japan against them!” (76; tr. 63). There is an internal contradiction in Sanshirō, as the text shows: on the one hand, Sanshiro's musings on the various kinds of "whiteness," on the other Hirota's comments on whiteness as fixed and homogenous. In the secondary scholarship, Hirota has often been equated with Sōseki himself, and precisely because of this, his views have been privileged. However, it is clear that Sanshirōs reflections on the internal hierarchy that exists between Westerners, as well as the various instances in the text that use racial tropes to organize the modern world in which Sanshirō takes place, destabilize the view that Hirota posits.

Even among the Tokyo elites, there exists a racialized hierarchy that defines them. The constant reminder that Sanshirō is a Kyūshū "black" man is one such example, but women are of course not exempt from this dynamic. Mineko, the heroine with whom Sanshirō falls in love, is endowed with many markers of whiteness: she is talented in English; Sanshirō is always noticing her "white teeth"; she has a white flower with her when Sanshirō first sees her; Sanshirō is awed by her Western-style living room. Many of the male characters further refer to her as "an Ibsen woman.” Interestingly however, her skin is described as follows:

[Sanshirō] thought about the skin of the young woman he had seen by the University pond. It was a tawny, foxlike shade, the color of a lightly toasted rice cake, its texture incredibly fine. That was the only way for a woman's skin to be (34; tr. 27). 
In contrast, Yoshiko, a sister of Nonomiya, the man whom, we presume, Mineko was going to marry, is described as aojiroi ("pale" but literally "blue-white"), despite being a Kyūshū woman. Why are these racial markers present? Both Mineko and Yoshiko are "white" to the extent that they are sisters of Tokyo Imperial University graduates, are well-educated, and are expected to marry into the elite circle. Yet the decisive difference is that Nonomiya's wealthy parents, who send money to buy Yoshiko a violin, are alive, while Mineko's are not. This becomes apparent when Mineko's brother Satomi Kyōsuke decides to marry. Mineko must be married off first, as her brother can only take care of one dependent. Mineko and Yoshiko are exchangeable to the degree that they are both sisters of elites. So as to highlight this point, the man Mineko marries at the end of the novel is someone who had initially asked for Yoshiko's hand. Yoshiko had the luxury to refuse to marry, but Mineko did not. It is as if Sōseki is highlighting the fact that race is about class and privilege.

As Shibata Shōji has shown, Tokyo elites in the novel are endowed with a racial duality. ${ }^{7}$ Again, Sanshirō is a Kyūshū "black" boy at Tokyo Imperial UniversityShibata in fact remarks that shiro, the term for white, can be found in Sanshirōs name. ${ }^{8}$ Mineko, with all her markers of whiteness, has tawny skin. Hirota Sensei, allegedly the most sophisticated intellectual, who has a nose that is "so very straight it looked Western," is referred to as "great darkness" (idainaru kurayami) $(14$, tr. $11 ; 128$, tr. 103). Shibata attributes such duality predominantly to the tension between the "modern" and "premodern," or more specifically, he claims that it represents "not only [Japan's] inability to rid itself of the premodern, but [that] modernization is being controlled precisely by it." He equates this with Sōseki's understanding of modernity. ${ }^{9}$ Although I agree to an extent, it does not fully explain the complexity of this duality.

To further explore this point, let us continue to dwell on the representation of the center and periphery in Sanshirō. Interestingly, there is a strange temporal lag established between Tokyo and Kyūshū: in comparison to Tokyo, Kyūshū "was far away and had the fragrance of the past, of which Yojirō called the years before Meiji 15" (80; tr. 65). Yojirō also says to Sanshirō, "You just arrived from the provinces (inaka) of Kyūshū. Your brain is still back in Meiji 1" (72; tr. 59). On the one hand, Kyūshū represents the "past" from which Tokyo, as a "white" center, has already grown out of. However, Kyūshū is also valorized as a "nostalgic" site throughout the text. The nostalgic image of the mother constantly appears in the mind of Sanshirō as he tries to acclimate to Tokyo. When Sashirō first meets Yoshiko, another Kyūshū woman, she is described like this: "She smiled at him, moving the spare flesh of her cheeks, and her pallor took on a nostalgic (natsukashii) warmth," which evokes "a shadow of his mother at home far away" (59; tr. 49). ${ }^{10}$ In addition, Kumamoto may be associated with "blackness" and "backwardness," but it is not without "light." Omitsu is a black-faced woman but her name, mitsu (光), also suggests "brightness.” If Kyūshū is simply backward 
and premodern, why is it associated with "lightness" and a profound sense of nostalgia?

In more ways than one, Kyūshū is a site that is arrested in the past, a place that is not contaminated by the hustle and bustle of the city that is overwhelmed by "whiteness." Kumamoto, or the inaka in general, is often posited as a site of authenticity for any given nation-state. It is a place that is putatively left behind by the center, the movement toward civilization, but it is also a site that retains the precontaminated self. In this sense, it has a double role in sustaining the modern structure of the nation state. First, it becomes a reference point by which the center constitutes itself as superior and more progressive. Second, it is redefined as an unsullied place where the authentic "natives"-those who have yet to be contaminated by the center-exist. Of course, this space can only be putatively posited, because no place can be fully free of the movement toward modernization, as Sōseki was well aware. This is a structural issue for any nation-state. The countryside retains the remnant of the past while the center becomes increasingly "white," ostensibly destroying the national authenticity it once had. In such a way, the "fictive ethnicity" that binds the national community finds its home." This cannot be characterized simply as a tension between the "premodern" and "modern"-it is the structure of modernity itself.

\section{THE LITERARY HISTORY MODEL} AND SŌSEKI'S INTERNAL FOCUS

As we have seen, there is a tension within which Sōseki posits racial tropes. On the one hand, there are, as in "Mankan tokoro dokoro," examples of what we may refer to as "vulgar racism," animalizing the coolies that he saw in Manchuria and describing them as "filthy." Yet, on the other hand, Sōseki also frees race from biologism and ethnic categories, and uses racial tropes to hierarchize those within the same ethnic nation. How does such duality play out in his theories?

Just like Ueda Kazutoshi, Sōseki engages with the literary history model I introduced in the previous chapter with Hippolyte Taine, which posits race as a defining index by which to compile works of literature. As we have seen, literary historians appropriated such models to posit a national collective with a shared history. Inscribed within it was an internal focus, where the texts were constantly linked to people's shin-teki seikatsu (internal lives) and kanjō shisō (emotions and thoughts). Ueda was no different in this regard. Despite his ultimate departure from it, Ueda retained the internal focus of this model because kokugo was defined as a means to solidify the national community. Sōseki's decision to revert to psychological theories in his definition of what he calls "literary substance" is not unrelated to such a focus on internal life. Moreover, literary history also used the historical divisions that corresponded with origin (kigen), development (hattasu), transformation (hensen), and decline (suitai). When Sōseki says, "I vowed to determine what 
psychological necessity there was for literature-for its emergence, its development and its decline," he was very much in the same vein as the history of his day. ${ }^{12}$

This internal focus that Sōseki deployed is inextricably linked to the objective of Bungakuron, which he lays out in his famous preface to the work. He ventured to "resolve the most essential question: What is literature?" after becoming aware of the following:

In reflecting on my own past ... I realized that, despite lacking a solid scholarly foundation in classical Chinese, I nonetheless believed myself able to appreciate fully the Confucian classics. Of course, my knowledge of English was not particularly deep, but I did not believe it to be inferior to my knowledge of classical Chinese. For my sense of like and dislike between the two to be so widely divergent despite my having roughly equal scholarly abilities must mean that the two were of utterly different natures. In other words, what is called "literature" in the realm of the Chinese classics and what is called "literature" in the realm of English must belong to different categories and cannot be subsumed under a single definition (SZ 18:9; tr. 44).

Many scholars have written on this well-known passage. Despite his "equal scholarly abilities" in English and classical Chinese, Sōseki could not understand why his sense of "like and dislike between the two [could] be so widely divergent." Based on the divergence of his "taste," therefore, Sōseki sought a definition of "literature" that could accommodate the works of kangaku and English. In other words, he sought a universal definition of "literature" that transcends national, cultural, and linguistic categories.

In order to clarify how Sōseki sets out to do so, let us briefly examine the famous formula $(\mathrm{F}+\mathrm{f})$ that he posits as "literary substance" (bungakuteki naiyō). For Sōseki, literary substance is represented through this formula, where F refers to "focal impressions or ideas" and $\mathrm{f}$ signifies emotive factors that are attached to F. It is important to understand $\mathrm{F}$ within the waveform of consciousness model: $\mathrm{F}$ is at the summit of the waveform as the focal point (where an idea or impression exists) and it is accompanied by $\mathrm{f}$ (emotions) at the lower fringes of consciousness. In other words, at a given moment, a given idea or impression appears to have focal intensity. When another F follows, the former F loses focus and is peripheralized in our consciousness.

This F is by no means easy to grasp. It is clearly in the mind, but Sōseki is silent as to how it gets there. When F constitutes itself as F, it is already an impression or a concept in the mind that is divorced from the specificity of expression. That is to say, he is silent about the process of mediation that invariably exists for $\mathrm{F}$ to be itself in the first place. In addition, the quotes he uses throughout Bungakuron are primarily derived from English sources, but the "Englishness" of the quotes are never brought to the fore. Moreover, he further refuses to translate them, whether the original be English, Japanese, or kanbun. The linguistic hierarchy that invariably exists between these languages are erased even in the act of writing Bungakuron. That is to say, all the languages are devoid of relation to one another. 
It is probably obvious by now that Sōseki's choice to appropriate the internal focus inscribed in these literary histories critically departs from both Ueda and the literary historians. Following Taine's formula of "race-milieu-moment," literary historians sought specifically to produce a shared sense of "Japanese-ness" in the texts they compiled. Ueda, departing from this project and severing kokugo from "Japanese-ness," sought to define kokugo as an imperial language, hence a "white" language, whose most authentic speakers were yamato minzoku. What may have appeared to be a radical departure on the part of Ueda seems rather tame in comparison to what Sōseki attempted. By seeking to be equal to the West, Ueda reinforced the global racial organization within which Japan found itself, while Sōseki tried to posit $(\mathrm{F}+\mathrm{f})$ in a context completely severed from the global hierarchy of nation-states and of racial organization altogether.

Sōseki thus attempts to posit a linguistically-neutral entity in his formula $(F+f)$, but there is an inevitable tension that arises from positing a universal, linguistically-neutral entity in order to define literary substance. ${ }^{13} \mathrm{He}$ is forced to theorize the manner in which to represent $(\mathrm{F}+\mathrm{f})$. It is precisely for this reason that he turns to rhetoric. ${ }^{14}$ What was important for Sōseki is that rhetoric not only deals with representation, but traditional rhetoric assumes a universal idea that is unaffected by space and time. Its view of literature was represented by the famous phrase of Aristotle, "Poetry is finer and more philosophical than history; for poetry expresses the universal, and history only the particular." Poetics posits the idea through rhetorical tropes and figures, as it lends itself to the universal.

This view was one that was still prevalent among aesthetic theories of the eighteenth century. ${ }^{15}$ With the trend toward empiricism, theorists began to privilege sensation and the direct experience of nature over the indirect experience of nature via linguistic representation. Nevertheless, they deemed that the degree of pleasure that these experiences produced was stronger in the latter than the former. Joseph Addison, for example, says the following about comparing nature and art:

If we consider the works of nature and art, as they are qualified to entertain the imagination, we shall find the last very defective in comparison of the former; for though they may sometimes appear as beautiful or strange, they can have nothing in them of that vastness and immensity, which afford so great an entertainment to the mind of the beholder. ${ }^{16}$

Yet later he says the following:

The pleasures of these secondary views of the imagination, are of a wider and more universal nature than those it has when joined with sight; for not only what is great, strange, or beautiful, but anything that is disagreeable when looked upon, pleases us in an apt description. ${ }^{17}$

In effect, "art" may be defective in comparison to "nature," but the pleasures of description are "wider and more universal" than the experience of nature by 
sight alone. As such, when mediated by language, nature is made more universal than nature itself. Language is not defined as a means for mimesis, but a means to the universal. This view was certainly not limited to Addison, but was a perspective shared by the aesthetic theories of such writers as Lord Kames and Edmund Burke. ${ }^{18}$

Catering to such idea of the universal behind traditional rhetoric, Sōseki thus attempted to retain $\mathrm{F}$ as a linguistic-neutral entity. Yet precisely because of this model, he inherited the problematic of direct and indirect experience, which perhaps unwittingly leads him into a bind. Sōseki's discussion on direct and indirect experience appears most concretely in Book II, Chapter 3, where he discusses the quantitative and qualitative changes in the emotive factor $\mathrm{f}$. In his discussion of the illusions that are attached to emotive $\mathrm{f}$, he says:

It goes without saying that an emotive $f$ that arises from direct experience and one that arises from indirect experience are different in terms of strength and content. This difference is the reason that things that are not acceptable in the natural world under ordinary circumstances become acceptable; things that are unpleasant to the ear or conditions ordinarily unbearable in the natural world can produce pleasure when transformed into indirect experience. In other words, when things that we do not consider beautiful or things that we long to eliminate both mentally and physically appear as $\mathrm{f}$ in literature, not only do we reserve our apprehension, but we at times tend to welcome them (SZ 18:113). ${ }^{19}$

Sōseki refers to this process as extraction (chūshutsu), which is a process of dissociation of self, morality, and intellect from the "real." For example, what one may deem terrifying in real life can take on beauty in literary expression. The "self" consciously or otherwise dissociates him or herself from real terror (and from the real eminent danger) and sees beauty in its representation.

What this discussion betrays is the very fact that $(\mathrm{F}+\mathrm{f})$ is a linguistic medium, which goes directly against Sōseki's attempt to neutralize it. If $\mathrm{F}$ is always already $\mathrm{F}$, then whether the experience is direct or indirect should not even become a problem. ${ }^{20}$ Critics have often noted the importance of universality in Bungakuron. However, they have linked it primarily to psychological theories, and as such, have often severed the link between language and F. Too often blindly following Sōseki's argument without questioning his confusion or contradictions, not many scholars have questioned the dilemma Sōseki found himself in.

There is also another glaring contradiction in Bungakuron. Despite all these attempts to universalize F and sever it from language, Sōseki uncritically posits a national community. This appears most compellingly in his positing of shūgōteki F (aggregate or group F), a discussion of which occurs in Book V of Bungakuron. We know that Sōseki was rather invested in this discussion, as he heavily edited his notes on Book $\mathrm{V}$ upon publication. Here he moves from the realm of psychology to sociology, from individual consciousness to collective consciousness. ${ }^{21}$ 
There are three types of group F, though the first, which he calls imitation (mogiteki ishiki), is perhaps the most pertinent:

We call 'imitative' that consciousness easily dominated by outside forces. By dominated we mean to say that as it moves from A to B, it naturally falls into step with others and takes a similar course of action. In other words, it is the type of consciousness that arises from the imitation of taste, "isms," and the experience of others. Imitation is a necessary social glue. A society without imitation would be like a heavenly body ungoverned by the laws of gravity. It would splinter into pieces and before long would collapse altogether. ... The ability to live in a society of adults without inviting constant mishaps indicates that one's thought, one's actions, and one's language (gengo) are adapted to that society (SZ 18:320-21; tr. 123-24).

Sōseki then goes on to say that while "normal imitation is done with subjective imitation," there are other forms of imitation that "are commanded by nature." These include "an imitation that is forced upon us by something stronger than individual will. Imitation tends to banish irregularities from society and bring each of its members into an orderly and equal (byōdō) array" ( $S Z$ 18:321-22; tr. 125). "Imitation," in other words, is a "glue" that sustains a community, which is "natural" or "commanded by nature." Moreover, it is quite compelling that this community is, among other things, defined by "thought" and "language." Such positing of a community is on a par with Hippolyte Taine's "race-milieu-moment," in which it is assumed that a given community has, inherent in itself, a natural commonality in "thought" and "language." In addition, it is one that aligns "its members into an orderly and equal array." Equality, as we saw in the previous chapter, is one major ideology of the nation-state which invariably hierarchizes its members, as differences will inevitably be identified. What Sōseki posits here, in other words, is the foundation of a racially-organized world order. Despite his rigorous analysis of the various categories he deploys, Sōseki is curiously silent on how such a "collective" comes into being. It is simply assumed. In effect, the racial hierarchy that he erased by concealing the means of representation is reintroduced in such a positing of group F. Nowhere in Bungakuron does he attempt to reconcile this contradiction.

\section{BELLETRISTIC RHETORIC AND SŌSEKI'S “TASTE”}

Let us now turn to another branch of rhetoric with which Sōseki engaged. Just as dominant as the psychological-philosophical vein of rhetoric was belletristic rhetoric, which is of particular interest here because of its emphasis on the development of "taste." Taste, it should be recalled, was the very reason why Sōseki began this monumental project in the first place. Let me first provide a brief discussion of the trends in belletristic rhetoric both in England and in Japan to contextualize Sōseki's project. Practitioners of belletristic rhetoric sought to cultivate people's taste through literary appreciation. The most prominent practitioner of 
belletristic rhetoric was Hugh Blair, whose Lectures on Rhetoric and Belles Lettres (1783) was widely read. Belletristic rhetoric thus engaged with the ongoing debate that developed throughout the eighteenth century on taste as a discriminator of aesthetic judgment. Just like the psychological-philosophical vein of rhetoric, it emerged as a movement against classical rhetoric. With economic development and the concomitant creation of a new reading public, needs of course changed. For those who lived in the world of commerce and trade, the power of persuasion in English was more valuable than knowledge of Greek or Latin, which was a reflection of upper-class erudition. Characterizing this shift and the rise of belletristic rhetoric, Wilbur S. Howell noted that it was "a change from the convention of imperial dress to the convention of the business suit." ${ }^{22}$ Such a change also coincided with the development of nationalism, which further contributed to the shift toward English.

We must not forget that this shift was racialized. It was not a coincidence that English studies and belletristic rhetoric developed quickly in Scotland, as the need for formal training in English arose "to promote ethnic English culture among the Scottish middle class." ${ }^{23}$ The Scottish were, in other words, not "white," and in order to assume "white" status, they had to master "Englishness." Sōseki found himself in the middle of such a racialized setting when he studied in England at the turn of the century. He tells us in the preface to Bungakuron that he first went to Cambridge to pursue his studies, but he was quickly disillusioned and considered going "north to Scotland or across the sea to Ireland" ( $S Z$ 18:6; tr. 41). Ultimately, he decided against it, since he "quickly realized that both places were ill-suited for the purpose of practicing English" ( $S Z_{18}$ :6; tr. 41). The meaning here is that "white" English was only spoken at the center. But the very reason that he considered Scotland and Ireland is precisely because "rhetoric" and "literature" were being taught outside of England. ${ }^{24}$ In the mid-to-late eighteenth century, the University of Edinburgh developed a teaching curriculum of lectures based on selections taken particularly from English literature in order to produce young men with "cultivated English taste." ${ }_{25}$ In describing Blair's work, Robert Crawford says, in his Devolving English Literature, that "Blair's works had been geared to a task of cultural conversion, of Anglicizing upwardly mobile Scots to make them acceptable Britons." ${ }^{26}$ Racial hierarchy thus existed within one nation despite the seeming non-"biological" difference.

This exemplifies the "fictive ethnicity" around which a nation is produced. Along with pronunciation, "proper grammar," and so forth, the authentic imaginary majority possesses, within themselves, a "cultivated" taste to which all "nonwhites" must aspire. This question of aspiration returns us to the question of racial teleology, the movement to become "white." Such an ideal majority does not, of course, exist, and precisely for this reason it is never achievable. What is important, however, is that the reality of achievability is present to foster the desire to become the authentic majority. 
Works of belletristic rhetoric in Japan arose around the same time that literary histories began to be compiled, and closely followed their British counterparts in defining their own raison d'etre in the cultivation of taste. The first work of impact was Takata Sanae's Bijigaku (A Study of Belles Lettres, 1889), followed by Tsubouchi Shōyōs Bijironkō (Thoughts on Belles Lettres, 1893) and Shimamura Hōgetsu's Shin bijigaku (A New Study of Belles Lettres, 1902). ${ }^{27}$ Takata elsewhere preached the need to nurture "taste," the ability to distinguish the beautiful and non-beautiful, and explained that this was the primary reason he compiled Bijigaku. ${ }^{28}$ While the modes of categorization in Bijigaku, such as the figure of speech and style of composition, were adopted from works of Western rhetoric, most notably Bain's English Composition and Rhetoric, the examples were primarily taken from Japanese and Chinese poetry. ${ }^{29}$ Bijigaku, while establishing aesthetic criteria of style and expression, was the first to "cultivate the style of composition to express one's thoughts." Takata continues, "Only after studying rhetoric can one find a refined taste in literature; and once enlightened with a refined taste in literature, one's heart or mind will move toward loftiness and elegance, and further develop honor." ${ }^{30}$ The study of rhetoric, which according to Takata cultivates refined taste, ultimately leads one to loftiness and elegance, which embodies national character. I must add here that insofar as it is an aspiration and thus a movement, it also threatens the very concept of national character, hence the need for a fictive ethnicity that is anchored in the past.

These works, used as textbooks, produced the ideal form of "national character," but their obsessive catering to Western rhetoric and style betrays their desire to become "white" at two levels: they claim whiteness by showing that Japanese examples adhere seamlessly to Western-style rhetoric, and they promise that the "taste" that is cultivated through the use of such rhetoric is "white." It was not a coincidence that Takata argued that English should become Japan's official language until two years prior to the publication of Bijigaku. ${ }^{31}$ By virtue of the fact that these works were used as textbooks, they were endowed with an authority by which to judge what was (and what was not) cultivated taste. These texts became a standard by which the presumably "equal" speakers of the Japanese language were hierarchized.

Let us now see how Sōseki responded to this trend. As many critics have noted, the main concern with which Sōseki started out his project was how to theorize taste in universal terms. ${ }^{32}$ In this sense, Bungakuron should have been more about small $\mathrm{f}$ than large F. Sōseki spends most of this long treatise discussing F, but he takes up taste again in Bungaku hyōron. ${ }^{33}$ While contemporaneous studies of rhetoric sought to cultivate refined "national" taste, we again find Sōseki seeking "universality" in the domain of taste.

Sōseki first acknowledges that most experiences of taste are singular, that they very rarely match with others. But there are cases in which they do match, and some are actually a result of necessary correspondence. It is very rare, he says, to 
identify universal taste in the likes and dislikes of literary materials themselves, but we are very likely to find universality of taste in "order, length, and structure (keizoku shōchō) of materials used in literary works." ${ }^{34}$ In other words, this universal taste is a reaction not to the material itself but to "the relationship and distribution between the materials." This is what he identified as "form" (as opposed to literary substance) in Eibungaku keishikiron (On the Study of Form in English Literature, 1924).35 "Form," Sōseki argues, appeals to taste and can produce universal taste. Form is divided into three, descriptions of which he gives in English: “1) Arrangement of words as conveying the meaning, 2) arrangement of words as conveying combinations of sounds, 3) arrangement of words as conveying combinations of shapes of words. ${ }^{36}$ Of course, he does not argue that universal taste can be claimed in all three cases: in fact, Eibungaku keishikiron is all about where to identify that universality. For example, he argues that the "arrangement of words as conveying the meaning" is the easiest for which to claim universality because they appeal to the intellect. As long as the arrangement of words follows the "intellectual flow," the demands of the intellect (which is universal) will be met ( $S Z$ 33:12). On the other hand, he says that the "arrangement of words as conveying combinations of sounds"-including the rhythm, melody and sound of words-is the most difficult for which to claim universality. The focus of his rigorous search for universality in taste is clearly on the formalistic aspect of language.

Let us compare Sōseki's discussion to Hōgetsu's Shin bijigaku, which was also greatly influenced by the study of psychological-philosophical rhetoric and in many ways shares much of the rhetorical paradigm. Despite the apparent similarity, we find that Hogetsu arrives at completely opposite conclusions. In discussing the methods of study in rhetoric, Hōgetsu has the following to say:

There are two parts to a study that takes a word as a base unit: one that studies
the character of words and the other their mutual relationships. To study the char-
acter of the words, we identify their parts of speech based on types, and examine
their inflection, conjugation, and change based on their usages. . . The study of
relationships between words theorizes concord, government, and order. ${ }^{37}$ When
two or more words are strung together, concord refers to the agreement of gender,
number, tense and person; government refers to case relationship; and order refers
to the sequence of nouns, verbs, etc. These rules all come from the customs (shükan)
of a given national language. They embody national characteristics. Within the
respective national languages, what agrees with these rules ought to be deemed
right and those that disagree ought to be considered wrong because of its divergence
from custom.

When Hōgetsu attributes such rules to custom, he has in mind, for instance, inverted phrases that are not necessarily in "logical" order. Here is an example he provides: he claims that "boku wa Ōsaka e ikö" (I am going to Osaka) is just as grammatically correct as "ikō Ōsaka e" (To Osaka, let's go), but he suggests that 
it may not be so in other languages. ${ }^{39}$ According to Hōgetsu, therefore, rules that govern the sequence of words ought to be determined within a given national language because they embody national character.

For Sōseki, the formal aspect of language was a site of universality. Sōseki thus sought universality in the very area that his contemporaries sought national specificity. Sōseki's literary apparatus thus gives us a critical model by which to examine national literature and rhetoric, presenting itself as a foundation for multiple criticisms.

At the same time, however, we must again note Sōseki's duality. Despite these attempts to seek universality, he cannot escape positing the particular. Even Bungaku hyöron, a work that attempted to theorize "universal taste," is not exempt from this. Discussing the study of foreign literature, Sōseki claims:

Japanese people do not have enough practice in English to make out the nuanced shades and tones. Thus there will be times when a foreigner might say that a given expression is obnoxious, whereas we don't find it so. There will be times that we gloss over as a common phrase what is actually lofty and divine. Japanese people are not very perceptive about these things and hence are probably not as acute as those scholars in England. . . . Without a doubt, this problem arises from the difference in languages ... the common assumption that foreigners possess the standard by which to evaluate foreign literature, whereas we don't, and thus we must abide by their theory. ... Until now you thought a certain way about a given work, but, listening to the criticism of Mr. X-which is very different from yours and which appears rather forced to you-you conclude that what he feels must be correct since he is a native critic. You then think that what you felt before must have been a mistaken and vulgar feeling, and since it is a mistaken feeling, it must be corrected. . . You then begin to discard the feelings you had until then and move toward what you think is right (SZ 19:39-40; tr. 233-34).

As much as Sōseki is arguing against an uncritical valorization of native scholars' literary criticism, the units "we" (the Japanese) and "they" (the foreigners) remain completely fixed. That is to say, while he tries to critique the category of the "native," he remains in fact complicit with it, as the boundary between the self and other remains intact. Although Sōseki takes a critical stance via the creation of "Japanese-ness" in the development of bellestristic rhetoric in Japan, he here replicates the very units he questioned. Such an uncritical positing of the "Japanese" subject is, needless to say, integral to the racialized world order, which assumes a commonality and equality amongst those within the confines of Japan. It is a repetition of his Group F which he posited in Bungakuron, a collective that has "naturally" come together that shares language, thought, and action.

In lieu of a conclusion, I would like to end this chapter with an observation on Sōseki scholarship in North America. In light of the ubiquity of racial tropes in 
his works, it is rather astonishing that scholarship on Sōseki does not address it. In fact, the silence on racial tropes extends far beyond scholarly remiss, which is evident in the English translations of literary works. Take Sanshirō, for example. When Sanshirō notices the "skin color of women becoming progressively "whiter," the translator, Jay Rubin, renders the passage as follows: "he had noticed the complexions of local women getting lighter and lighter." ${ }^{\circ}$ I of course realize that translations of literary works need to read smoothly, and that they should avoid awkwardness in the English to make the work more accessible to the general public. But such racial erasure seems to be significant. I view this as symptomatic of our field, as it is consistent with other translations of modern Japanese fiction. Edwin Mcllelan, who translated Sōseki's Kokoro, commits a similar erasure. Here is the passage where the narrator describes the time he first spots Sensei at the beach: "I was in a relaxed frame of mind, and there was such a crowd on the beach that I should never have noticed him had he not been accompanied by a Westerner. The Westerner, with his extremely pale skin, had already attracted my attention when I approached the tea house." ${ }^{11}$ What is translated as "extremely pale skin" is in Japanese "sugurete shiroi hada", which should perhaps be translated as "supremely white skin." In the novel, this is a decisive moment in which Sensei is marked as "white." For Sensei is, as we later find out, a graduate of Tokyo Imperial University who is wealthy enough to live with his wife without working.

Such a tendency of racial erasure is of course not limited to the works of Sōseki. In the translation of Mori Ōgai’s “Maihime," or "Dancing Girl," by Richard Browning, when Toyotarō, the narrator/protagonist of this novella, first meets Elis, a German girl with whom he has an affair, he remarks how she was startled when he approached her "and stared at my yellow face" (ki naru omote). Browning translates this as "my sallow face." ${ }^{22}$ Elis's face, on the other hand, is described as "chi no gotoki iro no kao," literally "a face that is like milk," which Browning ends up rendering as "pallid face." ${ }^{43}$ The reference to his "yellow face" is an indication that Toyotarō is rather self-conscious of his "yellow-ness" in front of a "milky" white woman, but such an obvious indication of racialization is completely erased from the translation. I want to emphasize that I do not wish to disparage these translators. In fact, these works are all first-rate translations. However, we cannot simply brush these erasures aside as an attempt to avoid awkwardness in English. Rather, this is a structural problem of translation that reflects the field itself.

What then is the ideological ground upon which such effacement of racial tropes rests? While I can only provide a cursory observation here, it is first of all connected to the Cold War politics to which we owe the establishment of area studies, a structure of study with which we remain complicit even today. The translators I have cited are of the generation that was recruited to reconfigure the image of the "enemy Japanese" into that of the tamed, domesticated ally who were capable of understanding a "beauty" that was translatable to an American readership. This was vital in the Cold War era. At the same time, as Takashi 
Fujitani has shown, it was also crucial for the United States to present an antiracist image of itself within the new world order, which had tremendous impact on postwar policies vis-à-vis Japan. ${ }^{44}$

Furthermore, "literature" became a site where the "universality of the human condition" was to be debated and learned. ${ }^{45}$ Even the postwar SCAP-led educational reform designated literature as a vehicle for "the development of the human spirit." The Fundamental Law of Education (Kyōiku kihonhō, 1947) contains the following passage in its preface: "We shall esteem individual dignity and endeavor to bring up the people who love truth and peace, while education aimed at the creation of culture, general [fuhen] and rich in individuality, shall be spread far and wide." ${ }^{36}$ In response to such calls for reform, high school textbooks at the time featured literary history, and defined literature as a site where "universal man" was to be discussed. This narrative tells us that "world literature," regardless of "linguistic" or "racial" differences, represents a site of "mutual understanding" given the universality of the realm of literature. ${ }^{47} \mathrm{I}$ am certainly not trying to claim that translators were conscious of racial erasure, as we cannot establish any facile causal relation between such institutional policies and individual choices. However, it is not too hard to imagine that these external forces somehow worked to conceal the racial tensions so obviously present in the Japanese texts. This type of universalism violently effaces the racialized world order and naively equates all people under the category of "human." At the same time, however, this category retains a telos of "whiteness."

I must emphasize here that the Cold War scheme is but one manifestation of the structural problems governing modernity, in which racial hierarchy is produced and reproduced. As much as we like to believe that we are now beyond such naivete, we become complicit with such erasure if we do not reinscribe race in our study. 